\section{Zoysiagrass Establishment from Sprigs following Application of Herbicides, Nitrogen, and a Biostimulator}

\author{
M.J. Carroll, P.H. Dernoeden, and J.M. Krouse \\ Department of Agronomy, University of Maryland, College Park, MD 20742
}

Additional index words. Digitaria ischaemum, smooth crabgrass, Zoysia japonica, stolons, turfgrass

\begin{abstract}
Sprigs of 'Meyer' zoysiagrass (Zoysia japonica Steud.) were treated with urea nitrogen, a biostimulator, and one of three preemergence herbicides or one of two postemergence herbicides to hasten establishment in two field studies. Monthly application of $\mathrm{N}$ at $48 \mathrm{~kg} \cdot \mathrm{ka}^{-1}$ during the growing season had no influence on sprig establishment the first year, but slightly increased $(+5 \%)$ zoysiagrass cover the second year. Presoaking sprigs in a solution containing $\left(\mathrm{mg} \cdot \mathrm{L}^{-1}\right) 173$ auxin and 81 cytokinin, and iron at $1.25 \mathrm{~g} \cdot \mathrm{L}^{-}$

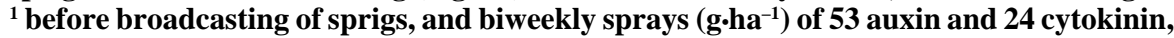
and iron at $0.2 \mathrm{~g} \cdot \mathrm{L}^{-1}$ or $\left(\mathrm{g} \cdot \mathrm{ha}^{-1}\right) 68$ auxin and 36 cytokinin, and iron at $1.45 \mathrm{~g} \cdot \mathrm{L}^{-1}$ after broadcasting sprigs had no effect on zoysiagrass cover or rooting. Preemergence and postemergence herbicide use generally enhanced zoysiagrass cover by reducing smooth crabgrass competition [Digitaria ischaemum (Schreb. ex Schweig) Schreb. ex Muhl]. Oxadiazon enhanced zoysiagrass coverage more than dithiopyr, pendimethalin, quinclorac, or fenoxaprop. Oxadiazon and dithiopyr provided similar levels of crabgrass control, but dithiopyr reduced 'Meyer' zoysiagrass midsummer root growth. Chemical names used: 3,5,-pyridinedicarbothioic acid, 2-[difluromethyl]-4-[2-methyl-propyl]-6-(trifluoromethyl)$S, S$-dimethyl ester (dithiopyr); [ \pm -ethyl 2-[4-[(6-chloro-2-benzoxazolyl)oxy]phenoxy] propanoate (fenoxaprop); 3-[2,4-dichloro-5-(1-methylethoxy)phenyl]-5-(1,1dimethylethyl)-1,3,4-oxadiazol-2-(3H)-one (oxadiazon); $N$-(1-ethylpropyl)-3,4-dimethyl2,6-dinitrobenzenamine (pendimethalin); 3,7-dichloro-8-quin-olinecarboxylic acid (quinclorac).
\end{abstract}

A major drawback limiting the use of 'Meyer' zoysiagrass is its slow rate of establishment. Zoysiagrass is usually established by planting vegetative plugs or by broadcasting stolons or sprigs. The use of plugs is preferred in situations where water is limited. Establishment by this method, however, is slower than broadcasting sprigs when water is readily available (Henry et al., 1988). Field research with plugs showed that frequent additions of N slightly delay 'Meyer' establishment in the year of planting (Fry and Dernoeden, 1987). In contrast, a greenhouse study indicated that 'Meyer' zoysiagrass stolon growth was increased with the addition of N (Juska, 1959). Moreover, Gibeault et al. (1988) observed that frequent applications of $\mathrm{N}$ to 'El Toro' zoysiagrass sprigs hastened its establishment.

When crabgrass (Digitaria spp.) and goosegrass [Eleusine indica (L.) Gaertn.] are a problem, zoysiagrass establishment from plugs can be hastened by using preemergence herbicides to reduce weed competition (Fry et

Received for publication 19 Jan. 1996. Accepted for publication 15 May 1996. Scientific Article no. 9215 and Contribution no. A7881 of the Maryland Agricultural Experiment Station, College Park. This work was supported in part with funding from Floratine Products, Collierville, Tenn. The cost of publishing this paper was defrayed in part by the payment of page charges. Under postal regulations, this paper therefore must be hereby marked advertisement solely to indicate this fact. al., 1986). Split applications of dimethyl 2,3,5,6-tetrachloro-1,4-benzenedicarboxylate (DCPA), $N$-butyl- $N$-ethyl-2,6-dinitro-4(trifluoromethyl)benzenamine (benefin), or $\mathrm{N}$ (2-methylcyclohexyl)- $N^{\prime}$-phenylurea (siduron), or a single application of 6-chloro$N, N^{\prime}$-diethyl-1,3,5-triazine-2,4-diamine (simazine) or oxadiazon increased zoysiagrass plug coverage in the initial year of establishment. Conversely, when these same herbicides were used at a site where 'Meyer' sprigs were broadcast, no increase in coverage was noted in the first year (Fry et al., 1986). The latter results were attributed to higher zoysiagrass coverage within the nonherbicidetreated sprigged areas when compared to the site established with plugs. Engel et al. (1968) reported that the growth of freshly planted 'Meyer' stolons was reduced when 6-chloro$N$-ethyl- $N$ '-(1-methylethyl)-1,3,5-triazine-2,4diamine (atrazine) or simazine were applied at $1.4 \mathrm{~kg}$ a.i./ha. The application of newer preemergence and postemergence herbicides (i.e., gramincides) to areas comprised of 'Meyer' zoysiagrass debris and sod ribbons, following sod harvest operations, suggests that these herbicides can hasten establishment from sprigs (Dernoeden and Carroll, 1992). However, preemergence herbicides can adversely affect rooting of zoysiagrass plugs (Fry et al., 1986). The effects of pre- and postemergence herbicides on the rooting of 'Meyer' zoysiagrass from sprigs has not been determined.

Biostimulators are materials of little or no fertilizer value that accelerate plant growth when used at low concentrations. Foliar application of an extract containing gibberellins and glycol kinetin exhibited biostimulatortype behavior when applied to Kentucky bluegrass (Poa pratensis L.) (Goatley and Schmidt, 1990, 1991). The extract increased the root and shoot growth of Kentucky bluegrass seedlings in the two- to three-leaf stage when the seedlings were transplanted 1 day after treatment (Goatley and Schmidt, 1990). Therefore, plant hormones possibly offer the potential to accelerate the rate of zoysiagrass establishment by stimulating root and shoot growth. The effect of plant hormone materials on the establishment of 'Meyer' zoysiagrass has not been studied.

Two studies were conducted to evaluate the effects of frequent $\mathrm{N}$ fertilization, preemergence and postemergence herbicides, and of a material containing auxins and cytokinins (biostimulators) on the rate of establishment and rooting of 'Meyer' zoysiagrass from sprigs.

\section{Materials and Methods}

Two field studies (Study I and II) were conducted at the Univ. of Maryland Turfgrass Research and Education Facility in Silver Spring. The two study sites were located adjacent to one another on a Sassafrass sandy loam (fine loamy, siliceous, mesic Typic Hapludalt) soil. The soil $\mathrm{pH}$ was 6.6 and contained $21 \mathrm{mg}$ organic matter/g soil.

The sites were tilled to a $20-\mathrm{cm}$ depth, cultipacked, and leveled using a steel mat. 'Meyer' zoysiagrass sprigs were broadcast at $19 \mathrm{~m}^{3} \cdot \mathrm{ha}^{-1}$ on 29 May 1991 in Study I and at 31 $\mathrm{m}^{3} \cdot \mathrm{ha}^{-1}$ on 29 May 1992 in Study II. The sprigs were firmly pressed into the soil surface by passing a grooved roller over the site four times in Study I. Because soil moisture was higher at planting in Study II, only two passes of the roller were made. Both sites received $100 \mathrm{~kg} \mathrm{P}$ and $\mathrm{K} / \mathrm{ha}$ at planting.

Study I. A randomized complete-block, split split-plot design with four blocks was used in Study I. Main plots were $3.6 \times 3.6 \mathrm{~m}$ and consisted of a single yearly application of one of four herbicides and a nonherbicidetreated control. The herbicide treatments included (a.i., kg.ha-1) 3.36 oxadiazon (2G), 0.56 dithiopyr $(0.25 \mathrm{G}), 0.84$ quinclorac $(75$ DG), and 0.20 fenoxaprop (1 EC). Oxadiazon and dithiopyr were applied preemergence to crabgrass seed germination on 30 May 1991 and 4 Apr. 1992 using shaker bottles. Quinclorac and fenoxaprop were applied postemergence on 25 June 1991 and 26 June 1992 using $\mathrm{a} \mathrm{CO}_{2}$-pressurized sprayer equipped with six 8602 Teejet nozzles (Spraying System Co., Wheaton, Ill.). The nozzles were located $0.6 \mathrm{~m}$ above the soil and were spaced $0.25 \mathrm{~m}$ apart. Postemergence applications were made in $660 \mathrm{~L}$ water/ha at a delivery pressure of $240 \mathrm{kPa}$. The subplot treatment consisted of a biweekly application of a biostimulator or none. The biostimulator (Per "4" Max Plus; Floratine Products, Collierville, Tenn.) contained a nonspecified mixture of auxins and cytokinins and was applied in $6.4 \mathrm{~L}$ water/ha 
to deliver $\left(\mathrm{g} \cdot \mathrm{ha}^{-1}\right) 53$ auxin and 24 cytokinin, and iron (ferrous sulfate) at $0.2 \mathrm{~kg} \cdot \mathrm{ha}^{-1}$, using the sprayer previously described. The biostimulator was applied seven times between 3 July and 4 Oct. in 1991 and 12 times between 18 May and 6 Oct. in 1992. The subsubplot treatment consisted of a single application of $\mathrm{N}$ at $96 \mathrm{~kg} \cdot \mathrm{ha}^{-1}$ from sulfur-coated urea (SCU) at planting, or the same amount at planting plus $\mathrm{N}$ at $48 \mathrm{~kg} \cdot \mathrm{ha}^{-1}$ from foliar sprays of water-dissolved urea on 3 July, 2 Aug., and 30 Aug. in 1991 and on 1 June, 29 June, 27 July, and 24 Aug. in 1992. The sub-subplots were $1.8 \times 1.8 \mathrm{~m}$.

Study II. A randomized complete-block, split-plot design was used in this study. The whole-plot treatment was one of four biostimulator application procedures and the subplot treatment was one of six herbicides. Whole plots were $5.5 \times 3.6 \mathrm{~m}$ and each treatment was replicated three times. The herbicide subplots were $1.8 \times 1.8 \mathrm{~m}$. Whole-plot treatments consisted of the following: 1) presoaking the sprigs for $15 \mathrm{~min}$ in a solution containing $\left(\mathrm{mg} \cdot \mathrm{L}^{-1}\right) 173$ auxin and 81 cytokinin, and iron (ferrous sulfate) at $1.25 \mathrm{~g} \cdot \mathrm{L}^{-1}$ immediately before broadcasting; 2) applying $6.4 \mathrm{~L} \cdot \mathrm{ha}^{-1}$ of a foliar spray that deposited $\left(\mathrm{g} \cdot \mathrm{ha}^{-1}\right) 103$ auxin and 48 cytokinin, and iron at $2.2 \mathrm{~kg} \cdot \mathrm{ha}^{-1}$ onto freshly broadcast sprigs; 3 ) procedures 1 and $2 ; 4)$ a nontreated control. The three wholeplot treatments receiving biostimulator at planting also received alternating foliar sprays of the biostimulator described in Study I and of an enhanced biostimulator solution (Per " 4 " Max Plus + Knife Plus; Floratine Products) that applied $\left(\mathrm{g} \cdot \mathrm{ha}^{-1}\right) 68$ auxin and 36 cytokinin, and iron at $1.45 \mathrm{~kg} \cdot \mathrm{ha}^{-1}$ every 2 weeks. The biostimulator foliar spray described in Study I and the enhanced biostimulator foliar spray were applied five times each between 1 June and 6 Oct. in 1992 and 1993. All biostimulator foliar sprays were applied as previously described. The herbicides, treatments, and application procedures were the same as those used in Study I except that pendimethalin (60DG) at $3.36 \mathrm{~kg}$ a.i./ha was added to Study II. Oxadiazon, dithiopyr, and pendimethalin were applied 1 June 1992 and 12 Apr. 1993, while quinclorac and fenoxaprop were applied 26 June 1992 and 25 June 1993. The entire area was fertilized with $\mathrm{N}$ from SCU at $96 \mathrm{~kg} \cdot \mathrm{ha}^{-1}$ at planting. No additional $\mathrm{N}$ was applied in Study II.

Cultural practices, data collection, and analysis. Both sites were irrigated as needed to keep the sprigs moist for the first 2 weeks following planting and thereafter as needed to prevent wilt. Beginning 2 months after planting, the turf was mowed at 3 to $4 \mathrm{~cm}$ every 7 to 14 days throughout the growing season. The percentage of ground area covered with zoysiagrass was estimated after the turf entered winter dormancy in each year and in early July of the second growing season. Zoysiagrass cover was visually assessed on a $0 \%$ to $100 \%$ linear scale, where $0 \%=$ entire plot area free of zoysiagrass and $100 \%=$ entire plot area covered. Visual estimates of smooth crabgrass cover also were collected in September of both years in each study.

Zoysiagrass rooting was measured on 18 Aug. in the second year of each study by collecting four, 2-cm-diameter, 11-cm-deep cores from each subplot (or sub-subplot in Study I) using a soil probe. The surface $1 \mathrm{~cm}$ of each core was removed before the remainder of core was placed in a plastic bag. The four cores from each plot were placed into a single bag. The combined sample was thoroughly washed to remove soil particles from the roots and dried at $50^{\circ} \mathrm{C}$ for at least 4 days. The samples were combusted at $500^{\circ} \mathrm{C}$ for 12 $\mathrm{h}$ and reweighed to obtain root dry weight.

Data were subjected to analysis of variance (ANOVA) using the SAS, PROC ANOVA statistical program (SAS Inst., 1985). Differences among treatment means were compared using Fisher's protected least significant difference test at $P \leq 0.05$.

\section{Results and Discussion}

There were no significant interactions among the biostimulator, $\mathrm{N}$, and herbicide treatments for any variable investigated in either study (Table 1). Hence, only individual simple treatment responses are presented.

Nitrogen. Monthly application of $\mathrm{N}$ from urea at $48 \mathrm{~kg} \cdot \mathrm{ha}^{-1}$ during the growing season had no effect on zoysiagrass cover in the initial year of establishment (Table 1). Establishment was hastened early in the summer of the second year with monthly applications of urea. Zoysiagrass coverage, however, was increased by only $5 \%$ ( $79 \%$ cover) when compared to areas not receiving supplemental $\mathrm{N}$ beyond the initial SCU application ( $74 \%$ cover). The slight beneficial effect of the additional $\mathrm{N}$ disappeared by the end of the second growing season as all plots approached or reached complete zoysiagrass coverage. Monthly additions of $\mathrm{N}$ had no effect on zoysiagrass rooting (Table 1). Monthly $\mathrm{N}$ also did not affect crabgrass coverage in the first year of Study I. In the second year, when crabgrass levels were much lower, weed coverage was increased from $14 \%$ to $22 \%$ in plots treated monthly with $\mathrm{N}$ (data not shown).

Herbicides. Zoysiagrass cover was markedly increased in oxadiazon-treated plots in the initial year of establishment (Table 2). Oxadiazon-treated plots had five to six times better zoysiagrass cover ( $52 \%$ to $69 \%$ ) than nonherbicide-treated areas (10\% to $11 \%)$. On all rating dates in both studies, oxadiazontreated areas had more complete zoysiagrass cover than the nonherbicide-treated areas. No other herbicide consistently had higher zoysiagrass coverage, when compared to nonherbicide-treated areas. Plots treated with dithiopyr had three times more zoysiagrass cover at the end of the first growing season than nonherbicide-treated areas in Study I, but this beneficial influence was absent in Study II. Similarly, zoysiagrass coverage was not

Table 1. Analysis of variance mean squares for percent 'Meyer' zoysiagrass cover, percent crabgrass cover, and root mass of zoysiagrass.

\begin{tabular}{|c|c|c|c|c|c|c|c|}
\hline \multirow[b]{4}{*}{ Source } & \multirow[b]{4}{*}{ df } & \multicolumn{6}{|c|}{ Mean squares } \\
\hline & & \multicolumn{3}{|c|}{ Zoysiagrass cover } & \multicolumn{2}{|c|}{ Crabgrass cover } & \multirow[t]{2}{*}{ Root mass } \\
\hline & & \multicolumn{5}{|c|}{ Evaluation date } & \\
\hline & & 19 Feb. 1992 & 7 July 1992 & 7 Nov. 1992 & 1 Sept. 1991 & 2 Sept. 1992 & 18 Aug. 1992 \\
\hline \multicolumn{8}{|l|}{ Study I } \\
\hline Block & 3 & $1181^{\mathrm{Ns}}$ & $1141^{\mathrm{NS}}$ & $607^{\mathrm{Ns}}$ & $2992^{\mathrm{Ns}}$ & $788^{\mathrm{Ns}}$ & $0.0250^{* *}$ \\
\hline Herbicide $(\mathrm{H})$ & 4 & $7938^{* * *}$ & $5032^{* *}$ & $3697^{* *}$ & $16441^{* * *}$ & $8859^{* * *}$ & $0.0229^{* *}$ \\
\hline Error a & 12 & 615 & 644 & 611 & 1565 & 437 & 0.0030 \\
\hline Biostimulator (B) & 1 & $11^{\mathrm{NS}}$ & $65^{\mathrm{NS}}$ & $0^{\mathrm{NS}}$ & $228^{\mathrm{Ns}}$ & $12^{\mathrm{NS}}$ & $0.0011^{\mathrm{Ns}}$ \\
\hline $\mathrm{B} \times \mathrm{H}$ & 4 & $60^{\mathrm{NS}}$ & $17^{\mathrm{Ns}}$ & $14^{\mathrm{NS}}$ & $225^{\mathrm{Ns}}$ & $58^{\mathrm{NS}}$ & $0.0031^{\mathrm{Ns}}$ \\
\hline Error b & 15 & 61 & 56 & 27 & 272 & 29 & 0.0031 \\
\hline Nitrogen $(\mathrm{N})$ & 1 & $61^{\mathrm{Ns}}$ & $541^{\mathrm{NS}}$ & $3^{\mathrm{Ns}}$ & $53^{\mathrm{NS}}$ & $1044^{* *}$ & $0.0021^{\mathrm{Ns}}$ \\
\hline $\mathrm{N} \times \mathrm{H}$ & 4 & $59^{\mathrm{Ns}}$ & $79^{\mathrm{Ns}}$ & $14^{\mathrm{Ns}}$ & $158^{\mathrm{Ns}}$ & $176^{\mathrm{Ns}}$ & $0.0008^{\mathrm{Ns}}$ \\
\hline $\mathrm{N} \times \mathrm{B}$ & 1 & $125^{\mathrm{Ns}}$ & $2^{\mathrm{Ns}}$ & $32^{\mathrm{Ns}}$ & $3^{\mathrm{Ns}}$ & $3^{\mathrm{NS}}$ & $0.0061^{\mathrm{Ns}}$ \\
\hline $\mathrm{N} \times \mathrm{H} \times \mathrm{B}$ & 4 & $380^{\mathrm{NS}}$ & $100^{\mathrm{NS}}$ & $38^{\mathrm{Ns}}$ & $214^{\mathrm{NS}}$ & $151^{\mathrm{NS}}$ & $0.0013^{\mathrm{Ns}}$ \\
\hline Error c & 30 & 255 & 69 & 26 & 435 & 86 & 0.0021 \\
\hline Study II & & 23 Nov. 1992 & 6 July 1993 & 1 Dec. 1993 & 30 Sept. 1992 & 23 Sept. 1993 & 19 Aug. 1993 \\
\hline Block & 2 & $143^{\mathrm{Ns}}$ & $192^{\mathrm{Ns}}$ & $44^{\mathrm{Ns}}$ & $265^{\mathrm{Ns}}$ & $3^{\mathrm{Ns}}$ & $0.0106^{\mathrm{Ns}}$ \\
\hline Biostimulator (B) & 3 & $845^{\mathrm{Ns}}$ & $238^{\mathrm{NS}}$ & $12^{\mathrm{Ns}}$ & $48^{\mathrm{Ns}}$ & $9^{\mathrm{Ns}}$ & $0.0047^{\mathrm{Ns}}$ \\
\hline Error a & 6 & 379 & 248 & 26 & 280 & 21 & 0.0036 \\
\hline Herbicide $(\mathrm{H})$ & 5 & $2992^{* *}$ & $1586^{* *}$ & $108^{* *}$ & $8265^{* *}$ & $173^{* *}$ & $0.0043^{*}$ \\
\hline $\mathrm{B} \times \mathrm{H}$ & 15 & $147^{\mathrm{Ns}}$ & $52^{\mathrm{Ns}}$ & $7^{\mathrm{Ns}}$ & $96^{\mathrm{Ns}}$ & $6^{\mathrm{NS}}$ & $0.0005^{\mathrm{Ns}}$ \\
\hline Error b & 40 & 102 & 77 & 10 & 131 & 11 & 0.0013 \\
\hline
\end{tabular}

${ }^{* * *}$ Nonsignificant or significant at $P \leq 0.05$ or 0.01 , respectively. 
Turf Management

Table 2. Influence of preemergence and postemergence herbicides on percent 'Meyer' zoysiagrass cover.

\begin{tabular}{|c|c|c|c|c|c|c|c|}
\hline \multirow[b]{4}{*}{ Herbicide } & \multirow[b]{4}{*}{ Rate $^{x}$} & \multicolumn{6}{|c|}{ Zoysiagrass $\operatorname{cover}^{2}(\%)$} \\
\hline & & \multicolumn{6}{|c|}{ Evaluation date $\mathrm{e}^{\mathrm{y}}$} \\
\hline & & \multicolumn{3}{|c|}{ Study I } & \multicolumn{3}{|c|}{ Study II } \\
\hline & & 19 Feb. 1992 & 7 July 1992 & 7 Nov. 1992 & 23 Nov. 1992 & 6 July 1993 & 1 Dec. 1993 \\
\hline \multicolumn{8}{|c|}{ kg a.i./ha } \\
\hline Oxadiazon $2 \mathrm{G}$ & 3.36 & $69 \mathrm{a}^{\mathrm{x}}$ & $96 \mathrm{a}$ & $100 \mathrm{a}$ & $52 \mathrm{a}$ & $95 \mathrm{a}$ & $100 \mathrm{a}$ \\
\hline Dithiopyr $0.25 \mathrm{G}$ & 0.56 & $33 \mathrm{~b}$ & 79 a & $93 \mathrm{a}$ & $16 \mathrm{~cd}$ & $73 \mathrm{bc}$ & $94 \mathrm{c}$ \\
\hline Pendimethalin 60DG & 3.36 & --- & --- & --- & $12 \mathrm{~d}$ & $67 \mathrm{c}$ & $99 \mathrm{a}$ \\
\hline Quinclorac 75DG & 0.84 & $19 \mathrm{bc}$ & $77 \mathrm{a}$ & $97 \mathrm{a}$ & $34 \mathrm{~b}$ & $93 \mathrm{a}$ & $98 \mathrm{~b}$ \\
\hline Fenoxaprop 1EC & 0.20 & $30 \mathrm{bc}$ & $83 \mathrm{a}$ & $97 \mathrm{a}$ & $24 \mathrm{c}$ & $91 \mathrm{a}$ & $99 \mathrm{ab}$ \\
\hline Nontreated & 0.00 & $11 \mathrm{c}$ & $48 \mathrm{~b}$ & $63 \mathrm{~b}$ & $10 \mathrm{~d}$ & $80 \mathrm{~b}$ & $93 \mathrm{c}$ \\
\hline
\end{tabular}

Zoysiagrass stolons were broadcast on 29 May 1991 in Study I, and on 29 May 1992 in Study II.

y Zoysiagrass cover was visually assessed on a $0 \%$ to $100 \%$ linear scale, where $0 \%=$ entire plot area free of zoysiagrass and $100 \%=$ entire plot area covered with zoysiagrass.

${ }^{x}$ Mean separation within columns at $P \leq 0.05$ by Fisher's protected least significant difference test.

improved by pendimethalin in the first growing season in Study II. Furthermore, in the second growing season of Study II, early summer zoysiagrass coverage was $13 \%$ less in pendimethalin-treated plots when compared to nonherbicide-treated areas. Zoysiagrass cover was higher in quinclorac- and fenoxaprop-treated plots than in the nonherbicide-treated areas in the second year of Study I and in both years of Study II.

Crabgrass encroachment pressure was severe in the first year of both studies and in the second year of Study I (Figs. 1 and 2). Oxadiazon reduced first-year crabgrass cover to one-third the level found in the nonherbicidetreated areas in Study I (30\% cover) and Study II (23\% cover). Similar, but smaller, reductions in crabgrass cover occurred with dithiopyr in the first year of Study I (47\% cover) and II ( $26 \%$ cover). In the second year, oxadiazon and dithiopyr reduced crabgrass levels to $\leq 4 \%$ cover in both studies. Pendimethalin provided poor crabgrass control in the first year of Study II (55\% cover), but control was excellent in the second year (1\% cover). We do not know why pendimethalin provided little crabgrass control in the first year of Study II. Previous research at this site showed that a single midApril application of pendimethalin reduced smooth crabgrass levels by $96 \%$ (Dernoeden and Carroll, 1991).

The temperature between planting and the application of postemergence gramincides was higher in 1991 than in 1992 . There were 8 days in this interval when the air exceeded $35^{\circ} \mathrm{C}$ in 1991 , whereas it never exceeded $35^{\circ} \mathrm{C}$ during the same time period in 1992. The higher temperatures in 1991 resulted in crabgrass plants having two to four tillers at the time of gramincide application; however, in 1992, most crabgrass plants had two to three leaves. Quinclorac was ineffective when applied to two- to four-tiller crabgrass in the first year of Study I (Fig. 1). It was highly effective against two- to three-leaf crabgrass in the first year of Study II (Fig. 2). Fenoxaprop provided a level of crabgrass control similar to oxadiazon and dithiopyr in Study I (Fig. 1). In Study II, fenoxaprop-treated areas had lower levels of crabgrass than oxadiazon- or dithiopyr-treated areas in the first growing season (Fig. 2). In the second year of Study II, when crabgrass pressure was low, all herbicides provided excellent control ( $<1 \%$ cover $)$.

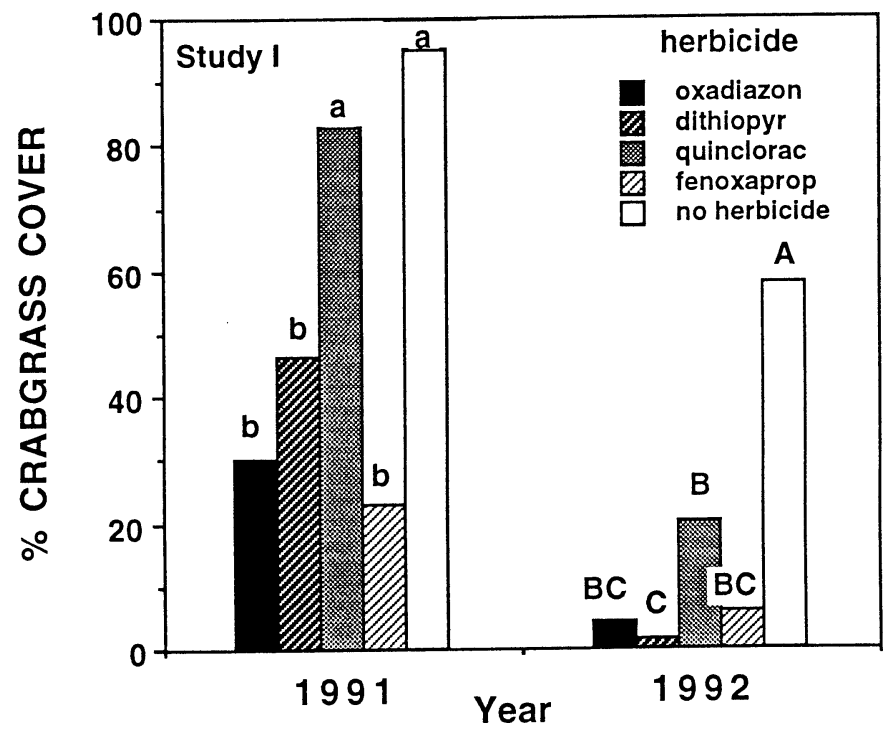

Fig. 1. Influence of herbicides on crabgrass cover, Study I, 1991 and 1992.

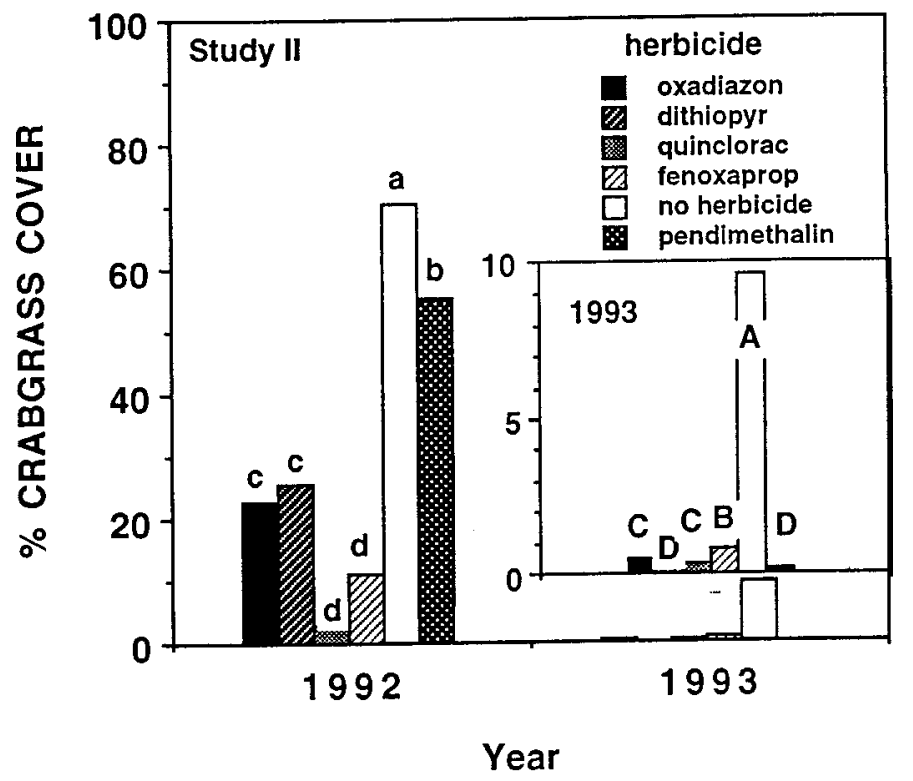

Fig. 2. Influence of herbicides on crabgrass cover, Study II, 1992 and 1993. The 1993 data are presented twice using different scales of resolution.

Dithiopyr was the only herbicide that adversely affected zoysiagrass root growth in both studies (Fig. 3). Dithiopyr-treated zoysiagrass had $39 \%$ and $26 \%$ less rooting mass than the nonherbicide-treated plants in Study I and II, respectively. Conversely, oxadiazon was the only herbicide that did not affect root growth in either study. Quinclorac 


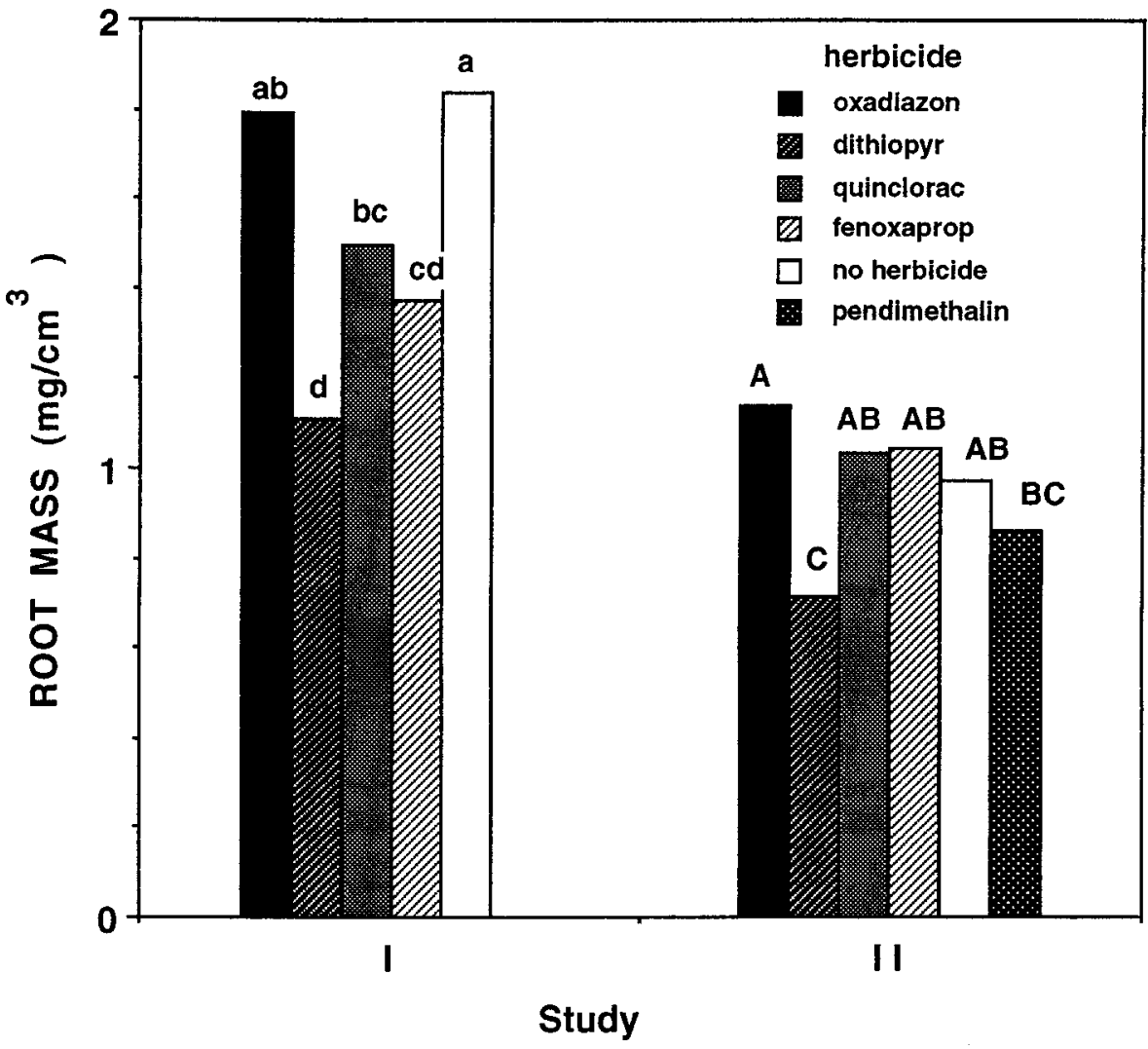

Fig. 3. Herbicide affects on 'Meyer' zoysiagrass root mass in the second year of Study I and II.

and fenoxaprop reduced root growth by $19 \%$ and $26 \%$ in Study I, respectively, but had no effect on rooting when compared to the nonherbicide-treated areas in Study II. Pendimethalin-treated zoysiagrass had root masses similar to the nonherbicide-treated areas in Study II. These data agree with previous studies that showed that oxadiazon did not affect rooting of 'Meyer' zoysiagrass plugs (Fry and Dernoeden, 1987) and that dithiopyr can reduce rooting more than pendimethalin when applied to a warm-season grass (Fishel and Coats, 1994). The data for quinclorac suggested that this compound slightly inhibited 'Meyer' zoysiagrass growth in Study I (Fig. 3).

In both studies, stunting of stolon growth lasted for 4 to 6 weeks following dithiopyr application. These observations and the
In summary, frequent applications of $\mathrm{N}$ had little effect on the establishment of 'Meyer' zoysiagrass sprigs. Similar results with plugs (Fry and Dernoeden, 1987) from previous studies indicate that frequent $\mathrm{N}$ fertilization will not appreciably affect the rate of 'Meyer' zoysiagrass establishment, regardless of the method of establishment used. In addition, the repeated use of a biostimulator containing auxin and cytokinin did not affect 'Meyer' zoysiagrass establishment. The use of herbicides to reduce or eliminate smooth crabgrass competition can hasten zoysiagrass establishment from sprigs. Dithiopyr, however, was injurious to 'Meyer' zoysiagrass roots.

\section{Literature Cited}

Dernoeden, P.H. 1989. Bermudagrass suppression and zoysiagrass tolerance to fenoxaprop, p. 285290. In: H. Takatoh (ed.). Proc. Sixth Intl. Turfgrass Res. Conf., Tokyo.

Dernoeden, P.H. and M.C. Carroll. 1992. Meyer zoysiagrass regrowth from sod debris as influenced by herbicides. HortScience 27:881-882.

Engel, R.E., C.R. Funk, and D.A. Kinney. 1968. Effect of varied rates of atrazine and simazine on the establishment of several zoysia strains. Agron. J. 60:261-262.

Fishel, F.M. and G.E. Coats. 1994. Bermudagrass (Cynodon dactylon) sod rooting as influenced by preemergence herbicides. Weed Technol. 8:46-49.

Fry, J.D. and P.H. Dernoeden. 1987. Growth of zoysiagrass from vegetative plugs in response to fertilizers. J. Amer. Soc. Hort. Sci. 112:286289.

Fry, J.D., P.H. Dernoeden, and J.J Murray. 1986. Establishment and rooting of zoysiagrass (Zoysia japonica) as affected by preemergence herbicides. Weed Sci. 34:413-418.

Gibeault, V.A., M. Leonard, and S. Cockerham. 1988. Nitrogen fertilization of 'El-Toro' zoysiagrass. Calif. Turfgrass Cult. 38:4-5.

Goatley, J.M., Jr., and R.E. Schmidt. 1990. Seedling Kentucky bluegrass growth responses to chelated iron and biostimulator materials. Agron. J. 82:901-905.

Goatley, J.M., Jr., and R.E. Schmidt. 1991. Biostimulator enhancement of Kentucky bluegrass sod. HortScience 26:254-255.

Henry, J.M., S. Tjosvold, and V.A. Gibeault. 1988. Zoysiagrass establishment. Calif. Turfgrass Cult. $38: 1-4$.

Juska, F.V. 1959. Response of Meyer zoysia to lime and fertilizer treatments. Agron. J. 51:81-83.

SAS Institute. 1985. SAS user's guide: Statistics. version 5. SAS Inst., Cary, N.C. 